\title{
Differential Effect of Wortmannolone Derivatives on MDA-MB-231 Breast Cancer Cells
}

\author{
ULYANA MUNOZ ACUÑA ${ }^{1,2}$, ROBERT W. CURLEY JR ${ }^{2}$, NIGHAT FATIMA ${ }^{3,4}$, \\ SAFIA AHMED ${ }^{5}$, LENG CHEE CHANG ${ }^{4}$ and ESPERANZA J. CARCACHE DE BLANCO ${ }^{1,2^{*}}$ \\ ${ }^{1}$ Division of Pharmacy Practice and Science and ${ }^{2}$ Division of Medicinal Chemistry and \\ Pharmacognosy, College of Pharmacy, The Ohio State University, Columbus, OH, U.S.A.; \\ ${ }^{3}$ Department of Biotechnology, Quaid-i-Azam University, Islamabad, Pakistan; \\ ${ }^{4}$ Department of Pharmaceutical Sciences, Daniel K. Inouye College of Pharmacy, \\ University of Hawaii at Hilo, Hilo, HI, U.S.A.; \\ ${ }^{5}$ Department of Microbiology, Quaid-i-Azam University, Islamabad, Pakistan
}

\begin{abstract}
Background/Aim: The survival rate of women diagnosed with triple-negative breast-cancer (TNBC) remains low. Hence, this study aimed at the chemical and biological optimization of furanosteroid derivatives for the treatment of this type of malignancy using TNBC cells. Materials and Methods: Semi-synthetic analogs of wortmannolone (1-6) that negatively affected the aberrant pathways in tumor cells were evaluated in hormoneindependent breast cancer cells using western blot and cellcycle analysis. Results: Wortmannolone derivatization generated $N F-k B$ inhibitors as new lead structures for further development. Compound (3) was found to be the most significantly active lead. Conclusion: Structure-activity analysis in the present study showed that acetylation of the hydroxyl groups and substitution on $\mathrm{C} 3$ and $\mathrm{C} 17$ of wortmannolone enhanced biological activity. Alphasubstitution of the acetyl group in $C 3$ on ring A (compound $3)$ resulted in ROS inducing effect; however, presence of an acetyl group in $\beta$-position of $C 3$ displayed the highest $N F-\kappa B$ p65 inhibitory activity $(0.60 \mu M)$.
\end{abstract}

The triple-negative breast-cancer (TNBC) cells lack expression of receptors sensitive to growth factors and hormones, and do not present estrogen, progesterone, or Her2/neu receptors. It has been estimated that $10-15 \%$ of diagnosed breast cancer subtypes are identified as TNBC cell

Correspondence to: Esperanza J. Carcache de Blanco, Ph.D., College of Pharmacy, The Ohio State University, Lloyd M. Parks Hall 500 W. 12th Avenue, Columbus, OH 43210, U.S.A. Tel: +16142477815 , Fax: +1 6142921335, e-mail: carcache-de-blan.1@osu.edu

Key Words: Furanosteroids, NF-kB p65, ROS, K-Ras, wortmannolone, breast cancer cells. types (1). Survival rate of women diagnosed with this specific type of malignancy remains low (2). At present, there are no targeted therapies to treat TNBC, and new anticancer agents remain to be developed to provide better outcomes for patients with this aggressive type of metastatic cancer.

Therefore, agents that trigger the formation of reactive oxygen species (ROS) above the tolerable threshold level, represent one possible strategy through which cell death can specifically be induced in TNBC cells. Hyperformation of ROS may selectively sensitize cancer cells and induce cell death. In this study, the anti-proliferative effects of furanosteroids that negatively affect the redox-balance in MDA-MB-231 TNBC cells were characterized and their intracellular effects were evaluated. In previous studies wortmannolone was found to produce an intracellular imbalance between prooxidants and antioxidants. Thus, six compounds derived from wortmannolone (1-6) were evaluated for ROS inducing effect in the triple-negative MDA-MB-231 cell line (Figure 1). Although a natural analog of wortmannolone previously isolated, wortmannin, has been extensively studied, no ROS-inducing effect has previously been reported to our knowledge. Herein, the downstream effect and cytotoxicity of the prooxidant furanosteroid derivatives were assessed as part of this study.

It has been previously reported that oxidative stress may affect several cancer related pathways. The formation of ROS in cancer cells produces genotoxicity, chromosomal instability, and DNA damage (3). More specifically, elevated ROS levels in cancer cells appears to affect regulatory elements, such as the transcription factor NF- $\mathrm{kB}$ and is suggested to have a fundamental role in tumor progression (4). Moreover, it is possible that ROS promotes the phosphorylation of IKB or alternatively acts as an activator by promoting DNA binding, without having a significant 


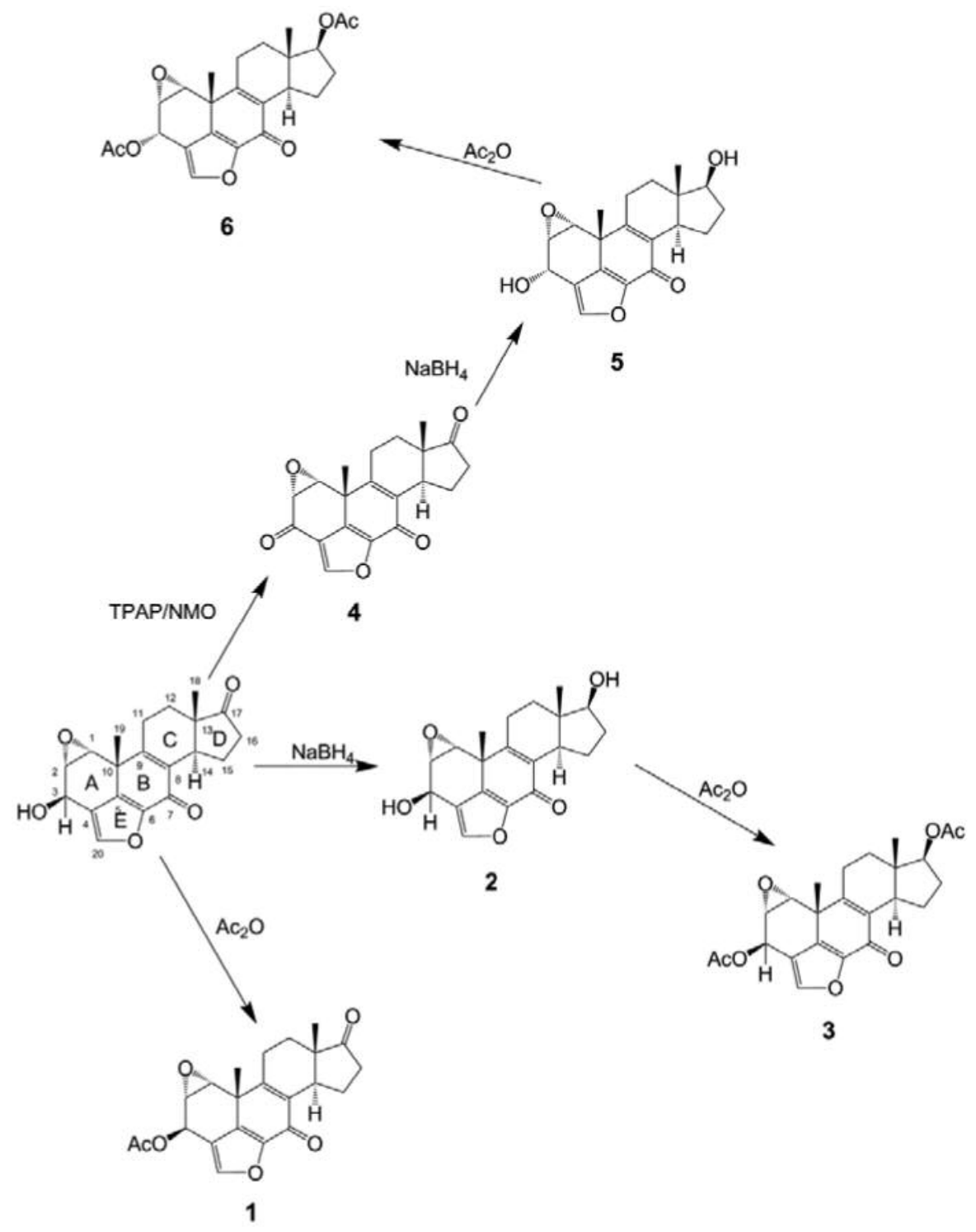

Figure 1. Synthetic route of furanosteroid derivatives, compounds (1-6).

impact on PI3K-dependent signaling $(5,6)$. Thus, we evaluated the effect of these ROS inducing agents on mediators of the NF-kB and K-Ras pathway.

\section{Materials and Methods}

Chemicals, reagents, antibodies and working solutions. Dichloromethane (DCM), 4-methylmorpholine N-oxide (NMO), tetrapropylammonium perruthenate (TPAP), 4-(dimethylamino)pyridine (DMAP), ethanol, $\mathrm{NaBH}_{4}, \mathrm{NH}_{4} \mathrm{Cl}, \mathrm{MgSO}_{4}$, daunomycin, vitamin $\mathrm{C}$, hydrogen peroxide and $\mathrm{HCl}$ were obtained from Sigma-Aldrich (St. Louis, MO, USA). Rocaglamide was purchased from Enzo Life Sciences, Inc. (Farmingdale, NY, USA). Bradford protein assay kit, Supersignal Femto LumiGLO kit and human recombinant tumor necrosis factor $\alpha$ (TNF- $\alpha$ ) were obtained from Thermo Scientific (Rockford, IL, USA). Lithium dodecyl sulfate sample loading buffer (LDS), Nu-PAGE 10\% SDS-PAGE Bis-Tris gel, SeeBlue ${ }^{\circledR}$ Plus2 PreStained Standard Ladder, and Purelink RNase A were obtained from Invitrogen (Carlsbad, CA, USA). Primary antibodies (anti-NF-kBp65 and $\mathrm{p} 50$, anti-IKK $\alpha$, and anti-IKK $\beta$ ) were purchased from Cell Signaling Technologies (Beverly, MA, USA). Anti-rabbit horseradish peroxidase (HRP)-conjugated antibody was purchased from Santa Cruz Biotechnology, Inc. (Santa Cruz, CA, USA). $\mathrm{FeSO}_{4}$ was obtained from Fischer Scientific Company (Fair Lawn, NJ). Daunorubicin was purchased from Tocris, Bristol, UK. Hydrogen peroxide was obtained from Fluka Biochemika, Steinhiem, Switzerland. Tris-buffered saline with tween-20 buffer (TBS-T), vitamin C, propidium iodine (PI), fluorescent probe 2',7'-dichlorfluorescein-diacetate (DCFH-DA) were obtained from Sigma Aldrich (St. Louis, MO, USA). 
Chemical optimization. Chemical reactions were performed following a previous published protocol for the preparation of the six known wortmannolone derivatives presented as part of this manuscript and the derivatives obtained were confirmed by nuclear magnetic resonance (NMR) and mass spectrometry (MS) (7). Wortmannolone $(15 \mathrm{mg})$ was dissolved in dry DCM $(5 \mathrm{~mL})$ and 5 equivalents of $\mathrm{NMO}$ and $25 \mathrm{mg}$ of powdered $3 \mathrm{~A}$ molecular sieve added. After cooling to $0^{\circ} \mathrm{C}, 7.5 \mathrm{~mol} \%$ of TPAP was added and the mixture stirred for $5 \mathrm{~min}$ at $0^{\circ} \mathrm{C}$ and then $1 \mathrm{~h}$ at room temperature. The reaction mixture was vacuum filtered through $300 \mathrm{mg}$ of 2:1 silica gel (40-63 $\mu \mathrm{m}) /$ diatomaceous earth with copious rinsing by DCM. Evaporation of solvent provided a residue, $4 \mathrm{mg}$ of which was retained as compound 4 (Figure 1). Compound $4(10 \mathrm{mg})$ was dissolved in ethanol $(2 \mathrm{ml})$ and cooled to $0^{\circ} \mathrm{C}$ and $5 \mathrm{mg}$ of $\mathrm{NaBH}_{4}$ added and the mixture stirred as it warmed to room temperature over $1.5 \mathrm{~h}$. Saturated ice cold $\mathrm{NH}_{4} \mathrm{Cl}(1 \mathrm{~mL})$ was added and the resulting mixture partitioned between ethyl acetate and water. The ethyl acetate layer was washed with brine and dried $\left(\mathrm{MgSO}_{4}\right)$, filtered and concentrated to give a residue, $4 \mathrm{mg}$ of which was retained as compound $\mathbf{5}$. Compound $5(5 \mathrm{mg})$ was dissolved in $1 \mathrm{~mL}$ of pyridine and $150 \mu \mathrm{l}$ of acetic anhydride and a catalytic amount of DMAP added and the mixture stirred at room temperature overnight. The reaction mixture was partitioned between ethyl acetate and $1 \mathrm{~N} \mathrm{HCl}$. The ethyl acetate layer was washed with brine, dried $\left(\mathrm{MgSO}_{4}\right)$, filtered and concentrated to provide a red residue retained as compound $\mathbf{6}$. Another $15 \mathrm{mg}$ of wortmannolone were used to generate compounds $\mathbf{1}$ and $\mathbf{3}$ in a similar fashion as compound $\mathbf{6}$. Compound $\mathbf{2}$ was prepared following a similar protocol as compound $\mathbf{5}$.

Cell culture. The colonic cancer cell lines (MDA-MD-231, HeLa, and HT-29) were purchased from American Type Culture Collection (ATCC), Manassas, VA. The cells were grown in DMEM or RPMI medium, supplemented with $10 \%$ (v/v) FBS and $10 \%$ antibioticantimycotic. The cells were kept at $37^{\circ} \mathrm{C}$ and in an atmosphere with $5 \% \mathrm{CO}_{2}$

ROS assay. MDA-MB-231, HeLa, and HT-29 cancer cells were seeded on 96-well plates and experiment run according to our previous published protocol. Then, the cells were treated with samples at different concentrations and incubated at $37^{\circ} \mathrm{C}$ with $5 \%$ $\mathrm{CO}_{2}$ for $4.5 \mathrm{~h}$. Further, cells were also treated with $\mathrm{H}_{2} \mathrm{O}_{2}(1.25 \mathrm{mM})$ (the positive control), and $\mathrm{FeSO}_{4}(0.2 \mathrm{mM})$, and probed with the fluorescent probe DCFH-DA $(5 \mathrm{mM})$ for $30 \mathrm{~min}$ at $37^{\circ} \mathrm{C}$. Other controls used for this assay include vitamin $\mathrm{C}$ and daunomycin. Fluorescence was measured at an excitation wavelength of $485 \mathrm{~nm}$ and an emission wavelength of $530 \mathrm{~nm}$ using a FLUOstar Optima fluorescence microplate reader (BMG Labtechnologies Inc., Durham, NC, USA). Each experiment was carried out in triplicate and was representative of at least two separate experiments.

$N F-k B$ assay. The EZ-Detect ${ }^{\mathrm{TM}}$ Transcription Factor Assay kit (Pierce Biotechnology, Rockford, IL, USA) was used to assess the ability of compounds to interfere with the specific binding between the biotinylated-consensus sequence for the corresponding factor and the active form of NF-kB. Experiment was performed following manufacturer instructions with few modifications. Nuclear extracts of HeLa cells treated with each compound at different concentrations and Tumor Necrosis Factor alpha (TNF- $\alpha$ ) were used for evaluation of NF-kB-p65 specific binding. The detection of NF-kB activity was based on the measurement of a chemiluminescent signal in a plate reader (FLUOstar Optima, BMG Labtechnologies GmbH, Inc). TNF$\alpha$-stimulated nuclear extract was used as a negative control and rocaglamide as a positive control in the NF- $\mathrm{kB}$ assay.

Immunoblotting. To confirm the effect of a compound on the NF$\mathrm{KB}$ pathway, cells were treated at different concentrations $(0.008$, $0.016,0.4,2.0$ and $10 \mu \mathrm{M})$. Briefly, cells were lysed with PhosphoSafe Lysis Buffer (Novagen) and lysates analyzed by western blot analysis with primary (1:1000) and secondary antibodies $(1: 2000)$. Protein concentration in the lysates was determined by using the Bradford protein assay kit and an albumin standard (Thermo Scientific). Absorbance was measured using the Fluostar Optima plate reader (BMG Labtech Inc, Durham, NC). Equal amounts of protein $(20 \mu \mathrm{g})$ were loaded together with LDS sample loading buffer (Invitrogen) and resolved using Nu-PAGE $10 \%$ SDS-PAGE Bis-Tris gels together with SeeBlue ${ }^{\circledR}$ Plus2 PreStained Standard (Invitrogen). Electrophoresis was performed using SDS-PAGE running buffer in a Nu-PAGE XCell SureLock Module from Invitrogen. Proteins were transferred to a polyvinyldiene fluoride (PVDF) membrane using transfer buffer, TBS-T. The blots were then blocked at room temperature using non-fat milk and probed using primary antibodies against each target protein using BSA in TBS-T overnight. Conjugated antibodies were detected using the chemiluminescent substrate Supersignal Femto kit from Thermo Scientific and relative band densities were determined.

\section{Results}

In our screening effort to identify secondary metabolites from endophytic fungi with ROS inducing effect, wortmannin was identified as a potent ROS inducing agent in triple negative MDA-MB-231 breast cancer cells (Figure 2). Wortmannolone, a natural analog of wortmannin, was also isolated from endophytic fungus of Taxus fauna as part of this study and chemically derivated (Figure 3). Six wortmannolone derivatives were generated (Figure 1) and structure activityrelationship studies showed that chemical modifications in position 3 and 17 have a significant impact on the biological activity of these derivatives. Some of the noteworthy changes were observed in the ROS, NF-kB-p65/p50, and apoptosis/cytotoxicity effects exerted by the derivatives against cancer cells, particularly MDA-MB-231 TNBC cells (Figures 4, 5 and 6). Figures 2 and 4 compare ROS effects between the derivatives and the controls (daunomycin, vitamin $\mathrm{C}$ and hydrogen peroxide). Table I summarizes the preliminary analysis of cytotoxicity, ROS fold induction, and NF-kB screening for wortmannolone and its derivatives.

\section{Discussion}

The ROS inducing effect of wortmannin in triple negative MDA-MB-231 breast cancer cells was so significant that it required $1000 \mathrm{x}$ difference in concentration to exhibit the same effect in the other two cancer cell lines tested (Figure 2). Wortmannin was the first phosphatidylinositol-4,5bisphosphate 3-kinase (PI3K) inhibitor identified; however, 


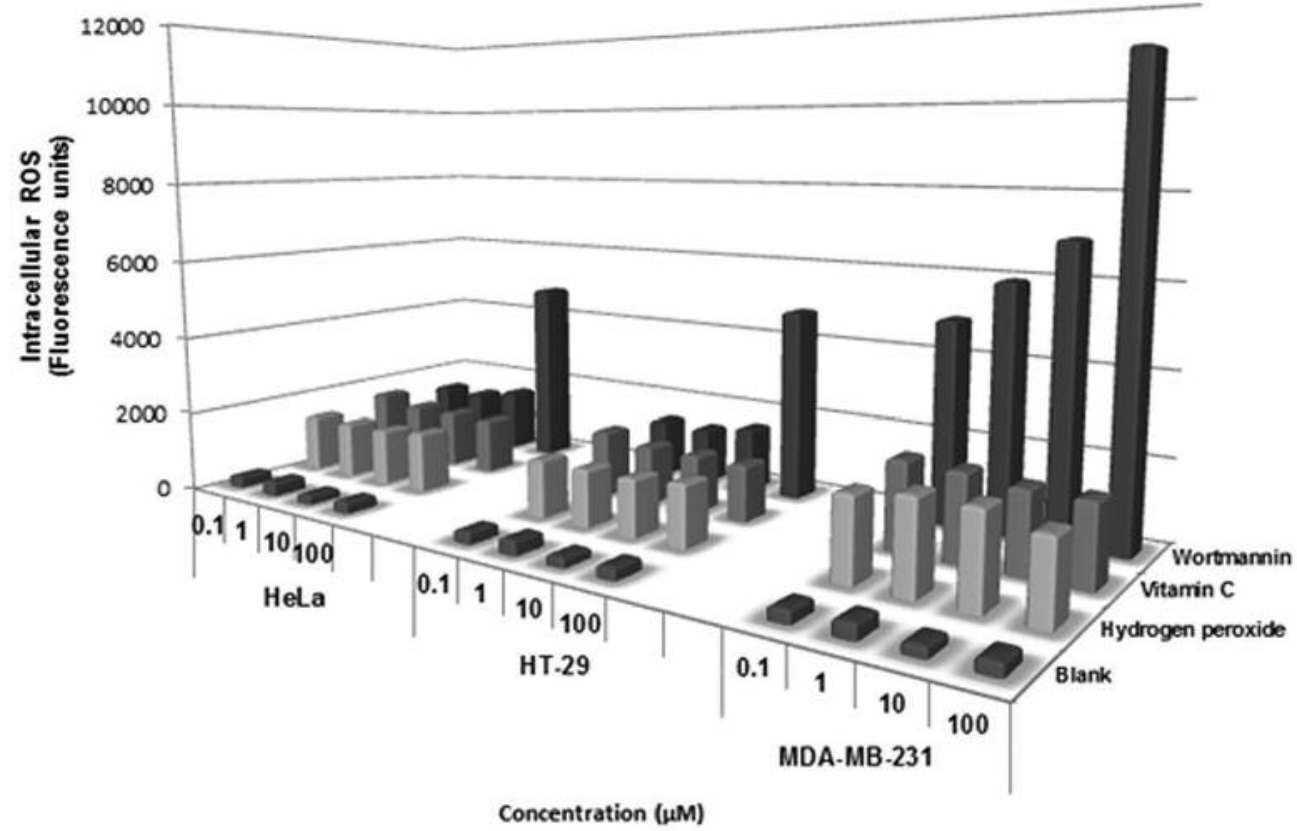

Figure 2. Induction of ROS in MDA-MB-231 cells. Screening of the ROS-inducing effect of wortmannin in three different cancer cell lines; HeLa cervical, HT-29 colon and MDA-MB-231 breast cancer cell lines. The ROS hyperformation was detected in MDA-MB-231 cells after 3 h of treatment at four different concentration levels. Strong ROS inducing effect was detected in the HeLa and HT-29 cell line when treated at the highest concentration level of $100 \mu \mathrm{M}$. The effect was compared to the positive control hydrogen peroxide $\left(\mathrm{H}_{2} \mathrm{O}_{2}\right)$ and negative control vitamin $\mathrm{C}$.

it was also found that it is a non-specific inhibitor that crossreacts with other PI3K proteins, suggesting potential side effects if developed as a drug (6). Wortmannolone has not been reported to exhibit the same PI3K effects as wortmannin. Hence, our study focused on chemical optimization of this natural analog of wortmannin by using previously reported chemical reactions. The chemical structure of wortmannolone [(Figure 3) $\mathrm{R}_{1}=\mathrm{OH}, \mathrm{R}_{2}=\mathrm{H}$, $\mathrm{R}_{3}=\mathrm{O}$ ] contains 20 carbons in a five ring structure (A-E) and two carbonyl groups at $\mathrm{C} 7$ and $\mathrm{C} 17$ on the $\mathrm{A}$ and $\mathrm{D}$ ring, respectively. The epoxide function is in the 1 and $2 \alpha$ position and in the $3 \beta$-position is the secondary hydroxyl $(\mathrm{OH})$ group on ring A. All wortmannolone derivatives (1-6) obtained were synthesized according to the previously reported procedure by Blight and Grove, 1986 (7).

These derivatives have not been tested using the conditions and assays reported in this peer-reviewed paper. The preparation of the previously reported analogs is shown in Figure 1 (7). In this structure-activity relationship study only modifications to the functional groups on $\mathrm{C} 3$ and $\mathrm{C} 17$ were assessed (Figure 3). All the furanosteroids 1-6 have derived structure from $1 \alpha, 2 \alpha$-epoxy-3 $\beta$-hydroxyandrosta5,8-dieno[6,5,4-bc]furan-7,17-dione and were screened for ROS inducing activity, NF-kB inhibitory, and cytotoxic activity in hormone-independent TNBC cells (7).

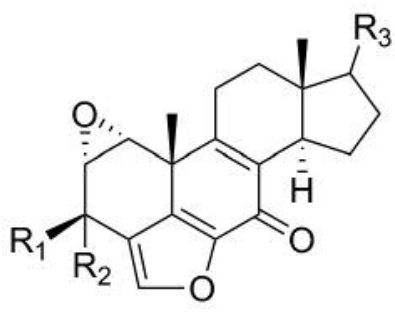

Figure 3. Furanosteroid skeletal structure that represents the groups $R_{l}$, $R_{2}$ and $R_{3}$ that were subjected to modification in the structure of wortmannolone.

Furanosteroids 1-6 displayed several different biological activities (Table I) $(8,9)$. Herein, the androsta-5, 8dienofuran structure was modified and subsequently the antiproliferative effects were examined for the obtained derivatives. The semi-synthetic derivatives 1-6 were tested in the hormone-independent breast cancer cell line MDAMB-231 and the relative potency was established. The $3 \beta$ hydroxyl group on ring A was substituted with an acetyl group to give acetylwortmannolone (1; as well as $\mathbf{3}$ and $\mathbf{6})$. The reduction of the ketone group at position-17 in ring D with sodium borohydride yielded compounds $\mathbf{2}$ and $\mathbf{5}$, and subsequently recrystallization from ethyl acetate yielded the 


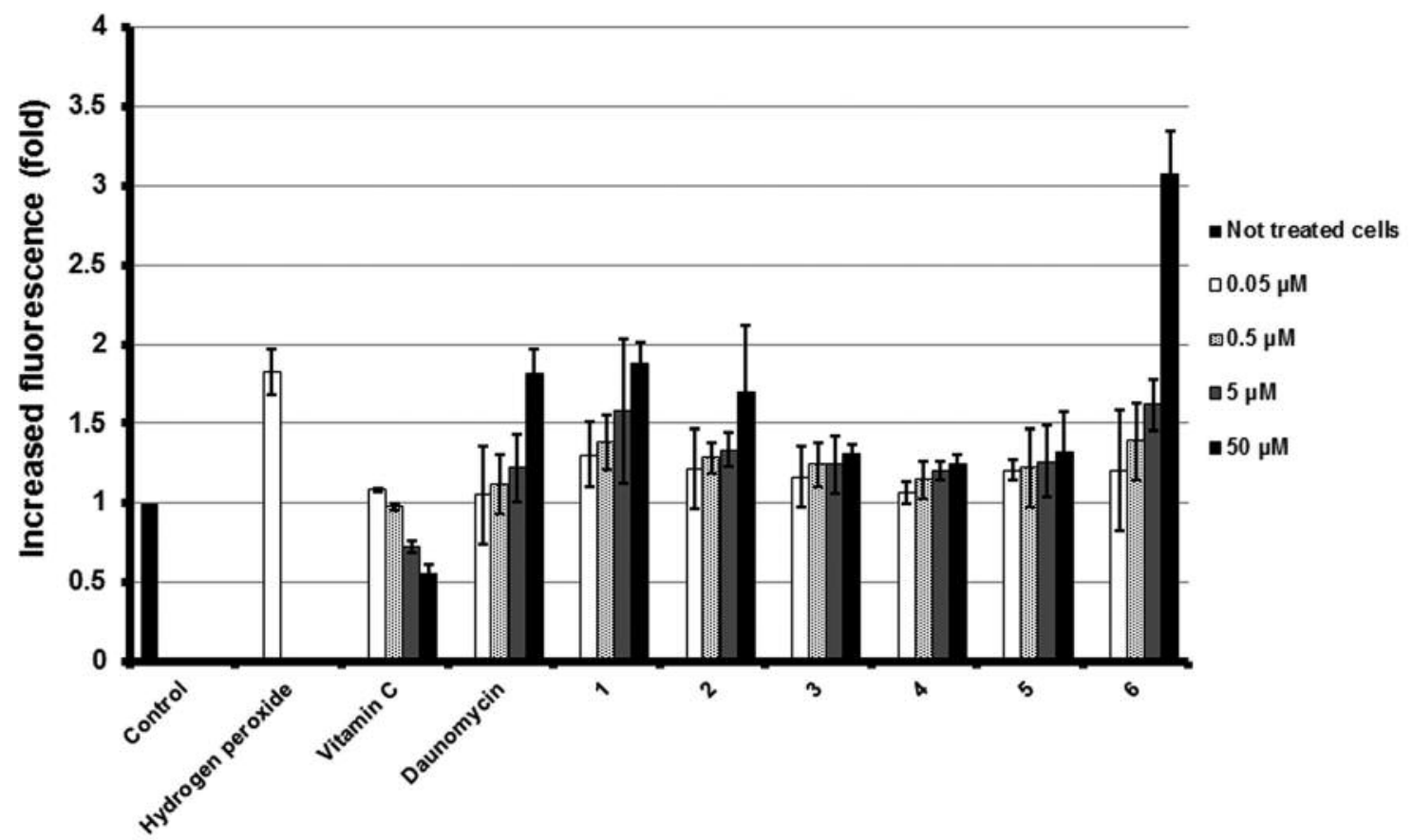

Figure 4. Evaluation of the ROS-inducing effect of compounds (1-6) in MDA-MB-231 cells. The effect was compared to the formation of ROS in non-treated cells. The negative control was treated with vitamin $C$ and the positive control was treated with daunomycin, a ROS generating anticancer agent. Compound $6(50 \mu \mathrm{M})$ showed 3-fold increase in intracellular ROS levels.

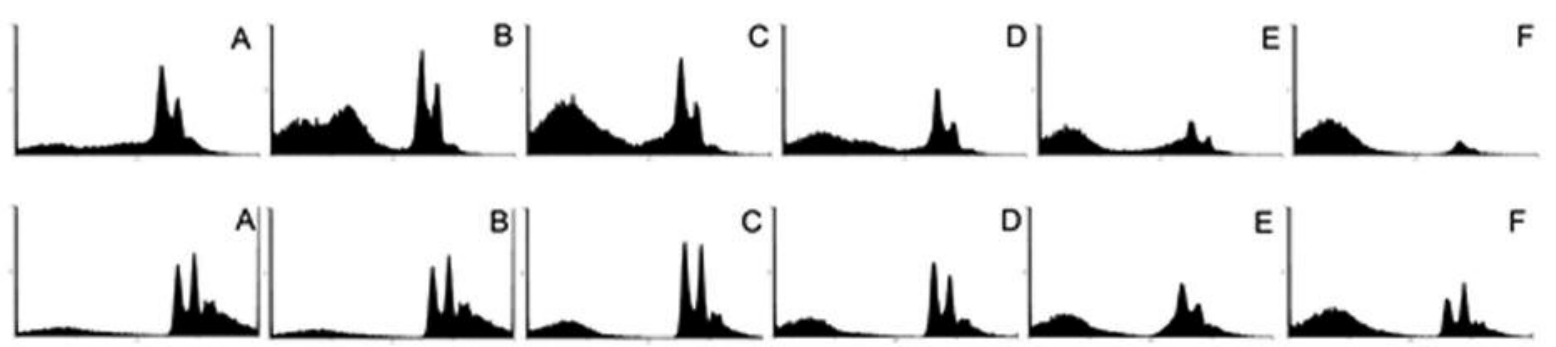

Figure 5. The apoptotic effect of compounds 3 and 6 are presented here at five different concentrations $[0.016 \mu M(B), 0.08 \mu M(C), 0.4 \mu M(D)$, $2.0 \mu M(E)$ and $10 \mu M(F)]$, in comparison with the untreated control $(A)$. The results are shown in DNA-histogram obtained from treated MDAMB-231 cells. An increased cell population was detected in sub $G_{1}$-phase using fluorescence activating cell flow cytometry (FACS) with increased concentrations of compounds $\mathbf{3}$ and $\mathbf{6}$, respectively.

diacetylated compounds 3 and $\mathbf{6}$. The directed synthesis of each of the analogs was confirmed by NMR and mass spectrometry with compound $\mathbf{1}, \mathrm{m} / \mathrm{z} 382$; compound $\mathbf{2}, \mathrm{m} / \mathrm{z}$ 342 ; compound $\mathbf{3}, m / z$ 426; compound $4, m / z 338$; compound $\mathbf{5}, \mathrm{m} / \mathrm{z} 342$; and compound $\mathbf{6}, \mathrm{m} / \mathrm{z} 426$.

When the semisynthetic derivatives 1-6 were screened for ROS inducing activity (Figure 1), the results showed that, potent ROS inducing effect was detected for acetylwortmannolone 6 (Figure 3; $\mathrm{R}_{1}=\mathrm{H}, \mathrm{R}_{2}=\mathrm{R}_{3}=\mathrm{OAc}$ ). The high ROS inducing effect was noted at the concentration of

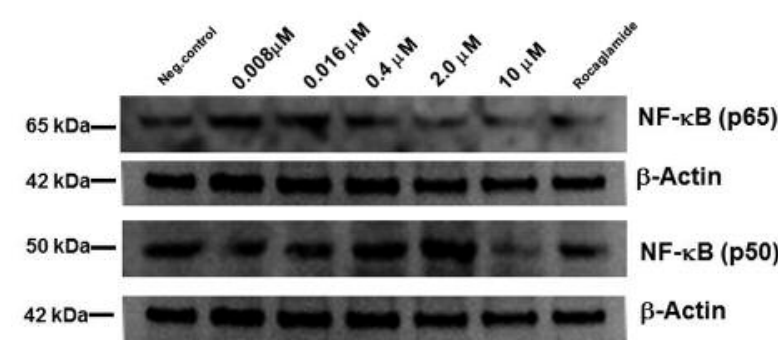

Figure 6. The western blot analysis of compound 3. The expression of $N F-k B$ subunit $p 65$ and subunit $p 50$ in treated MDA-MB-231 cells. 
Table I. Biological activity of compounds 1-6.

\begin{tabular}{|c|c|c|c|c|}
\hline \multirow[t]{2}{*}{ Compounds } & \multirow[t]{2}{*}{ Substituent } & \multirow[t]{2}{*}{$\operatorname{ROS}^{\mathrm{a}}$} & \multirow{2}{*}{$\frac{\text { Cytotoxicity }}{\mathrm{EC}_{50}(\mu \mathrm{M})}$} & \multirow{2}{*}{$\frac{\text { NF-kB inhibition }}{\mathrm{IC}_{50}(\mu \mathrm{M})}$} \\
\hline & & & & \\
\hline Wortmannolone & $\left(\mathrm{R}_{1}=\mathrm{OH}, \mathrm{R}_{2}=\mathrm{H}, \mathrm{R}_{3}=\mathrm{O}\right)$ & 1.72 fold increase & 0.004 & 2.06 \\
\hline 1 & $\left(\mathrm{R}_{1}=\mathrm{OH}, \mathrm{R}_{2}=\mathrm{H}, \mathrm{R}_{3}=\mathrm{O}\right)$ & 1.58 fold increase & 8.93 & 9.12 \\
\hline 2 & $\left(\mathrm{R}_{1}=\mathrm{OH}, \mathrm{R}_{2}=\mathrm{H}, \mathrm{R}_{3}=\mathrm{OH}\right)$ & 1.34 fold increase & 1.69 & 27 \\
\hline 3 & $\left(\mathrm{R}_{1}=\mathrm{OAc}, \mathrm{R}_{2}=\mathrm{H}, \mathrm{R}_{3}=\mathrm{OAc}\right)$ & 1.24 fold increase & 0.971 & 0.60 \\
\hline 4 & $\left(\mathrm{R}_{1}=\mathrm{O}, \mathrm{R}_{2}=\mathrm{H}, \mathrm{R}_{3}=\mathrm{O}\right)$ & 1.21 fold increase & 0.009 & 3.76 \\
\hline 5 & $\left(\mathrm{R}_{1}=\mathrm{OH}, \mathrm{R}_{2}=\mathrm{H}, \mathrm{R}_{3}=\mathrm{OH}\right)$ & 1.26 fold increase & 0.030 & NA \\
\hline 6 & $\left(\mathrm{R}_{1}=\mathrm{OAc}, \mathrm{R}_{2}=\mathrm{H}, \mathrm{R}_{3}=\mathrm{OAc}\right)$ & 1.62 fold increase & 0.027 & 3.06 \\
\hline
\end{tabular}

aReactive oxygen species fold increase.

5-50 $\mu \mathrm{M}$ and was compared to the ROS inducing effect of the positive control daunomycin and hydrogen peroxide $(0.05$ $\mathrm{mM})$, at corresponding concentrations. Compound $6(50 \mu \mathrm{M})$ showed a 3-fold increase in intracellular ROS levels; the apoptotic effect induced by ROS promoting agents was assessed using propidium-iodide and the cellular events were monitored using flow cytometry (Figure 5). The apoptotic effect was concentration-dependent for 6 in MDA-MB-231. In addition, the cytotoxicity in the MDA-MB-231 cells of $\mathbf{6}$ (Table I) was determined using the SRB (sulforhonamine B) assay after $72 \mathrm{~h}$ of incubation. In summary, the analog 6 displayed anti-proliferative effect and these findings suggested that oxidative stress induced by 6 was associated with apoptosis that was induced in the treated MDA-MB-231 cells.

Although, the ROS inducing effect of compound 1-6 did not correlate with the high cytotoxic effect displayed in MDA-MB-231 cells, 6 displayed a similar biological activity profile to wortmannolone, showing high cytotoxicity, ROS inducing activity, and NF-kB p65 inhibitory activity.

It has been revealed that NF- $\mathrm{kB}$ activation is thioalkylationsensitive and that the NF-kB p65 activity can be regulated by intracellular redox mechanisms (10). Thus, the effect of the derivatives (1-6) on the NF-kB assay (p65) was examined in this study. Compound $\mathbf{3}$ displayed three-fold higher activity than wortmannolone. Thus, the presence of acetyl groups at position 3 and 17 increased the NF-kB (p65) inhibitory activity. The effect was confirmed by immunoblot analysis (Figure 6). The data obtained suggested that acetyl groups may represent important functional groups to inhibit the NF$\mathrm{kB}$ activity of the subunit $\mathrm{p} 65$ binding to consensus region of the DNA. Moreover, the stereochemistry of the acetyl groups did have significance for the NF-kB inhibitory activity. The diastereomer compound $\mathbf{6}$ with a different stereochemistry of the acetyl group at position 3 in ring A, displayed five-fold less NF-kB inhibitory activity $(3.06 \mu \mathrm{M})$ than compound $\mathbf{3}$ $(0.60 \mu \mathrm{M})$. This suggested that the diacetylated derivatives 3 and 6 target different intracellular pathways in the MDA-MB231 cells. The obtained findings revealed that replacing the diacetyl function with hydroxyl substitution on $\mathrm{C} 3$ and $\mathrm{C} 17$ drastically reduced NF-kB inhibitory activity see 3 vs.2 (Table I). The study reveals that the steroid backbone structure and more specifically the furanosteroids, in particular, target the NF-kB pathway. The results showed that the binding of subunit p65 to the consensus sequence was negatively affected in MDA-MB-231 cells treated with compounds $\mathbf{1 , 3}, \mathbf{4}$, and $\mathbf{6}$, showing an inhibition concentration $<10 \mu \mathrm{M}$, even though not very potent NF-kB p65 inhibitory activity was detected for compound 1, 4 and 6 .

All compounds were evaluated for cytotoxicity against MDA-MB-231 cells (Table I) and the activity was compared to wortmannolone $\left(\mathrm{IC}_{50}=3.8 \mathrm{nM}\right)(1)$. The results indicated that derivative $4\left(\mathrm{R}_{1}=\mathrm{R}_{2}=\mathrm{O}, \mathrm{R} 3=\mathrm{O}\right)$ displayed potent cytotoxic activity in the MDA-MB-231 cell line $\left(\mathrm{IC}_{50}=9.1 \mathrm{nM}\right)$. The structure-activity relationship (SAR) analysis suggested that the distant keto-group at $\mathrm{C} 17$ present in the D-ring was essential for potent cytotoxic effect. Moreover, it appears that the stereochemistry of the $\beta$-3 hydroxyl $(\mathrm{OH})$ group present at carbon-3 does affect the cytotoxic effect, as shown by the displayed cytotoxic activity of compound $2(1.69 \mu \mathrm{M})$ and $5(0.03 \mu \mathrm{M})$.

In addition, compound 4 (Figure $3 ; \mathrm{R}_{1}=\mathrm{R}_{2}=\mathrm{O}, \mathrm{R}_{3}=\mathrm{O}$ ) showed K-Ras inhibitory activity when tested in the K-Ras inhibitory ELISA assay. The aberrant expression of K-Ras and the role of the K-Ras signaling pathway in the oncogenic process and early stages of tumorigenesis still remain to be characterized for the development of new therapeutic agents. Overall, it appears that prosurvival of K-Ras signaling affects the PI3K/Akt/MEK signaling pathway and further downstream leads to NF-kB activation. Therefore, the structure of furanosteroids may be modified and the K-Ras inhibitory effect may be enhanced/optimized through semi-synthetic methods.

The apoptotic effect was evaluated for compounds $\mathbf{4}$ and 6, the two derivatives with the highest cytotoxic and ROS inducing activities, respectively. The concentrationdependent apoptotic effect was induced by both compounds 4 and 6 . The results showed that treatment with compound 
$6(10 \mu \mathrm{M})$ led to $73.6 \%$ of the cell population being in subG1 phase (Figure 5). Thus, the high ROS inducing effect of 6 appears to induce apoptosis in treated MDA-MB-231 cells, suggesting the need for further studies on the potential of this derivative against breast cancer.

Similarly, treatment with compound $\mathbf{4}$, led to $31.5 \%$ of the cell population being in sub-G1 phase. Thus, it appears from the obtained results that the ROS inducing capacity of compound $\mathbf{4}$ was associated with potent apoptotic effects after 3 hours of treatment. It has previously been shown that the interference with the reduced intracellular antioxidant capacity and the thioredoxin system in MDA-MB-231 cells induce higher amounts of ROS $(11,12)$. Here, we have shown that higher amounts of ROS induce apoptosis of these TNBC cells.

In summary, the esterification of wortmannolone $\mathrm{OH}$ group at carbon 3 and 17 increases ROS inducing activity, and NF-kB inhibitory activity. Consequently, the diacetylwortmannolone showed increased biological activity in hormone-independent-cancer cells. The diastereomer, with $\beta-3$ substitution showed NF- $\mathrm{KB}$ inhibition in the MDA-MB231 cell line. Meanwhile, the hyperformation of ROS, produced by compounds $\mathbf{4}$ and $\mathbf{6}$, led to apoptosis in TNBC cells, MDA-MB-231 cells. The results from this study suggested that the furanosteroid derivatives are promising lead compounds as both are ROS inducing agents and NF$\mathrm{KB}$ inhibitors, exhibiting their effect through independent mechanisms. Thus, these analogs exert antiproliferative effects through two independent mechanisms of action, acting both as ROS inducing agents and NF- $\mathrm{kB}$ p65 inhibition in TNBC cells. Acetylwortmannolone targets two different intracellular pathways in the aggressive MDA-MB231 cancer cells; however, stereoselectivity and specific targeted NF-kB p65 inhibition was achieved by $\beta$ substitution at C-3. Thus, in this study, inhibitors of the prosurvival pathways NF- $\mathrm{KB}$ and K-Ras as well as ROS inducing agents were synthesized.

\section{Conclusion}

The undertaken study analyzed differential activity of semisynthetic furanosteroid derivatives of wortmannolone. One of the derivatives (compound 3) exhibited the most promising activity with great potential for further development. The SAR data provides the prospect of two potential different mechanisms of action and anti-proliferative effect of these furanosteroids. Further development of the most promising furanosteroid analogs into successful anticancer agents would require complementary in vivo studies to evaluate the anti-tumor effect of the wortmannolone derivatives. The combination of anticancer drugs with reactive oxygen species (ROS) generating agents, such as the furanosteroid derivatives, may selectively sensitize cancer cells to undergo apoptosis, and enhance the cancer cell cytotoxicity of existing regimens of chemotherapy.

\section{Acknowledgements}

The Authors greatly acknowledge the financial support from the College of Pharmacy, The Ohio State University and the diversity supplement P01 CA125066-S2 from the National Cancer Institute, $\mathrm{NIH}$, Bethesda, MD.

\section{References}

1 Pal S, Lüchtenborg M, Davies EA and Jack RH: The treatment and survival of patients with triple negative breast cancer in a London population. Springerplus 3: 553, 2014.

2 Steward L, Conant L, Gao F, Margenthaler JA: Predictive factors and patterns of recurrence in patients with triple negative breast cancer. Ann Surg Oncol 21: 2165-2171, 2014.

3 Guerreiro PS, Fernandes AS, Costa JG, Castro M, Miranda JP, Oliveira NG: Differential effects of methoxyamine on doxorubicin cytotoxicity and genotoxicity in MDA-MB-231 human breast cancer cells. Mutat Res 757: 140-147, 2013.

4 Gupta A, Rosenberger S F, Bowden GT: Increased ROS levels contribute to elevated transcription factor and MAP kinase activities in malignantly progressed mouse keratinocyte cell lines. Carcinogenesis 20: 2063-2073, 1999.

5 Flohé L, Brigelius-Flohé R, Saliou C, Traber M G, Packer L: Redox regulation of NF-kappa B activation. Free Radic Biol Med 22: 1115-1126, 1997.

6 McNamara CR and Degterev A: Small-molecule inhibitors of the PI3K signaling network. Future Med Chem 3: 549-565, 2011.

7 Blight MM and Grove JF: Viridin. Part 8.' Structures of the analogues virone and wortmannolone. J Chem Soc Perkin Trans 1: 1317-1322, 1986.

8 Urban NH, Chamberlin B, Ramage S, Roberts Z, Loria RM and Beckman MJ: Effects of alpha/beta-androstenediol immune regulating hormones on bone remodeling and apoptosis in osteoblasts. J Steroid Biochem Mol Biol 110: 223-229, 2008.

9 Graf MR, Jia W and Loria RM: The neuro-steroid, 3beta androstene 17alpha diol exhibits potent cytotoxic effects on human malignant glioma and lymphoma cells through different programmed cell death pathways. Br J Cancer 97: 619-627, 2007.

10 Kaileh M, Vanden Berghe W, Heyerick A, Horion J, Piette J, Libert C, De Keukeleire D, Essawi $\mathrm{T}$ and Haegeman G: Withaferin a strongly elicits IkappaB kinase beta hyperphosphorylation concomitant with potent inhibition of its kinase activity. J Biol Chem 282: 4253-4264, 2007.

11 Turturro F, Von Burton G and Friday E: Hyperglycemia-induced thioredoxin-interacting protein expression differs in breast cancer-derived cells and regulates paclitaxel $\mathrm{IC}_{50}$. Clin Cancer Res 13: 3724-3730, 2007.

12 Schulze PC, Yoshioka J, Takahashi T, He Z, King GL and Lee T: Hyperglycemia promotes oxidative stress through inhibition of thioredoxin function by thioredoxin-interacting protein. J Biol Chem 279: 30369-30374, 2004.
Received January 24, 2017

Revised March 13, 2017

Accepted March 14, 2017 